\title{
THE INFLUENCE OF LEADERSHIP, WORK CLIMATE AND SPIRIT ON ELEMENTARY SCHOOL TEACHER'S DISCIPLINE IN BATU AMPAR DISTRICT TANAH LAUT REGENCY
}

Sundari ${ }^{*}$, Aslamiah, Ngadimun

Magister Program of Educational Manajement, Lambung Mangkurat University Banjarmasin, Indonesia

\begin{tabular}{|c|c|}
\hline ARTICLE INFO & A B S T RACT \\
\hline \multirow[t]{2}{*}{$\begin{array}{l}\text { Article history } \\
\text { Received: June } \\
\text { Revised: August } \\
\text { Accepted: September } \\
\text { Keywords: } \\
\text { Leadership, Work Climate, } \\
\text { Spirit, Discipline }\end{array}$} & $\begin{array}{l}\text { Discipline is the attitude of willingness and willingness of a person to comply } \\
\text { with and obey the rules and regulations that apply around him. The purpose of this } \\
\text { study was to analyze the direct and indirect effects of leadership, work climate and } \\
\text { work spirit on the discipline of elementary school teachers in Batu Ampar District, } \\
\text { Tanah Laut Regency. This research is quantitative with cross sectional method and } \\
\text { using the technique of correlation. The study population was I } 65 \text { teachers and II7 } \\
\text { respondents were taken as the study sample by proportional e random sampling } \\
\text { technique. Data collection uses instrument questionnaires and data analysis using } \\
\text { test instruments (validity and reliability testing), descriptive analysis, classic } \\
\text { assumption test, linear regression analysis and path analysis. The results of this } \\
\text { study show that I) there is a positive and significant influence on the principal's } \\
\text { leadership directly on the disciplinary variables. 2) there is a significant and } \\
\text { positive influence school leadership directly on spirit Elementary School teacher. 3) } \\
\text { there is a positive and significant influence climate school work directly against the } \\
\text { teacher discipline. } 4 \text { ) there is a positive and significant influence climate school } \\
\text { work directly against the teacher spirit. 5) there is positive and significant influence } \\
\text { teachers' spirit directly to the discipline teacher. 6) there is a significant and } \\
\text { positive influence school leadership indirectly through the spirit of teachers to } \\
\text { discipline Elementary School teacher. 7) there is positive and significant influence } \\
\text { school work climate indirectly through the spirit of teachers to discipline } \\
\text { Elementary School teacher. }\end{array}$ \\
\hline & 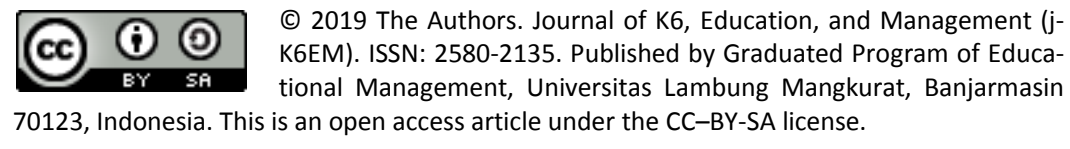 \\
\hline
\end{tabular}

*Correspondence: Sundari; E-mail: sundariplh@gmail.com 


\section{Introduction}

The teacher is the spearhead in education. Therefore the teacher must be able to provide exemplary at school, in the community and in the family. As an operational task teachers as leaders, administrators, educators, designers and counselors so that teachers not only deliver subject matter, evaluate, and analyze but also must pay attention to how the school culture and methods are chosen in delivering learning material also how to deal with problems resolved psychologically and educative (Sutarto, 20II, p. 25).

Once the importance of the role of the teacher in determining the success of education, for that a teacher must have high discipline on the tasks he carries out as mandated for civil servants as servants of the state. This fact requires teachers to have high discipline in carrying out their duties and functions, because the teacher is a character who becomes a role model for students and their environment. Discipline as obedience to the rules and norms of the life of the nation and state in force, which is carried out consciously and sincerely, physically. On the other hand, discipline is a tool for creating human behavior and order as a community group. Therefore, discipline means punishment or weighty sanctions governing and controlling behavior (Prijadarminto, 2003, p. 86).

(Suwatno, 20II, p. 59) stated that discipline is an attitude of willingness and willingness to obey and obey the rules and regulations that apply around them. Discipline is also influenced by good working relationships with fellow employees so that each employee will feel happy and calm in carrying out tasks in the office. While according to (Hasibuan, 2009, p. I03) discipline is the awareness and willingness of someone to obey all applicable rules and social norms. Awareness is the attitude of someone who voluntarily obeys all rules and is aware of their duties and responsibilities.

Teacher discipline in work can be said as a mental attitude that is reflected in the actions and behavior of a teacher based on established rules or regulations, a code of ethics, norms that apply in the school organization that are arranged together and have been agreed upon to achieve goals which have been set. Teacher professionalism will be formed beginning with the formation of self discipline as a teacher. Many mistakes claim to be professional teachers while the teacher is undisciplined. Therefore the key word for the formation of a professional teacher is the cultivation of self-discipline in the teacher (Prijadarminto, 2003, p. 7I).

Based on the results of preliminary observations obtained from observations and some data from the principal of Batu Ampar Subdistrict, Tanah Laut District, there are several phenomena that occur in the subject of teacher discipline. Teacher discipline has not been optimal yet, $\mathrm{p}$ this can be seen from the existence of teachers who leave school at working hours for reasons that cannot be accounted for, there are individual teachers who do not join the apple, quickly go home prematurely for no reason obviously, employees who are absent from work for health or necessity reasons family and the low commitment that the teacher has in working or teaching such as not making an annual program, semester program or not making a plan for implementing learning.

(Rivai, 20I4, p. II5) states that teacher work discipline is influenced by various factors, both internal and external factors. Internal factors are factors associated with one's nature, such as work motivation, work spirit, and work initiatives. External factors, namely factors originating from the environment such as the level of welfare, leadership style, firmness, supervision, and incentives. Wrong one factor that influences the discipline of school teachers, including the leadership of the principal. (Sutarto, 20I I, p. 42) states that leadership is the main problem in organizational management, organizational growth and development, pleasure whether or not someone works in an organization, and whether or not organizational goals are achieved, partly determined by whether or not the leadership applied by the organization concerned. On the other hand, the employee as a person has desires and needs, so all his actions must be oriented to the desires and needs that must be met. Therefore, the effectiveness of leadership must also be supported by policies that can encourage employees to be more disciplined .

Another factor that influences teacher discipline in schools is the work climate. The work climate in organizations can help organizations achieve organizational effectiveness. Litwin and Stringer defines the work climate as the system of information management and important environment factors on the attitudes of belief values and motivation of the people who work in particular organization (Wirawan, 2007, p. 122).

Another factor that can influence teacher work discipline is the teacher's work spirit. The spirit of work for the teacher is an impulse that arises from 
within, consciously or not to carry out his duties as a teacher in achieving his goals. With enthusiasm will foster a sense of more caring, responsible, loyal and disciplined in carrying out his duties as a teacher. (Suriansyah, 2015, p. 64) Therefore a teacher should have high enthusiasm. Teachers who have high enthusiasm in carrying out their duties as a teacher will surely encourage him to be disciplined in the task of educating, teaching, and training his students. Decreasing teacher spirit is characterized by a lack of encouragement for achievement, low responsibility in work or often called demotivation.

This study only examines the principal leadership factors, work climate and morale for teacher discipline, (Sugiyono, 2000, p.42) because leadership skills are still low in building good communication with teachers, besides that the work climate still needs to be improved and the work spirit of teachers still needs to be improved by the teaching profession. development is still not like training to improve knowledge and ability to teach.

\section{Methodology}

Types of research

The type of research used is quantitative research. According to quantitative research whose research data is in the form of numbers and analysis using statistics. The reason for using quantitative research, because the data in the form of figures collected can be useful, it must be $\mathrm{d} i$ if and analyzed first, so it can be used as a basis for a decision. This study also uses explanatory research methods. Explanatory research is to test relationships between hypothesized variables. According to the level of explosion including associative research that aims to find out relationships between two or more variables (Sugiyono, 2000, p.42). This research tries to express causation (causal or explanatory) in the form of influence between leadership headmaster, work climate and work spirit towards the work discipline of State Elementary School (SD) teachers in Batu Ampar District, Tanah Laut Regency which is formulated into the model path analysis both direct and indirect.

\section{Research Design}

The design of this study uses a cross sectional method, which is a study in which the variables in which free factors and dependent variables are observed at the same time (Prasetyo, 2005, p. 56). The design of this study was chosen because the researchers intended to reveal how much influence the independent variables were that of the principal's leadership $\left(X_{I}\right)$, work climate $\left(\mathrm{X}_{2}\right)$ and work spirit $\left(\mathrm{X}_{3}\right)$ on the dependent variable, namely the level of teacher work discipline (Y) Public Elementary School in Batu Ampar District, Tanah Laut Regency.

\section{Research Population and Samples}

The population in this study are all teachers of Elementary School in Batu Ampar District of Tanah Laut Regency amounted to I65 people consists of all class teachers who are civil servants. According to (Arikunto, 20I0, p. 67) if the research subjects are less than I00, it is better to take all, but if the subject is large or more than 100 , it can be taken between I0$15 \%$ or $20-25 \%$ or more. Given the size of the population in this study more than 100 respondents, then determine the size of the sample using Slovin formula as follows:

$$
n=N / I+N\left(e^{\wedge} 2\right)
$$

Information :

$\mathrm{N}$ : Number of Samples

$N$ : Total Population

e : Error tolerance for $(5 \%=0.05)$

Based on the above formula applied in this study, the obtained sample size amounted to II7 people. The sampling technique in this study was proportional e random sampling which is random sampling by taking into account the proportions that exist in members of the population (Arikunto, 2010, p. 69).

\section{Research Instrument}

The instrument of this study includes variables that will be observed in the study, which are designed in the form of questionnaires or questionnaires which include assessment and and questionnaire observations for each variable, namely, principals' leadership variables (XI), work climate (X2) and work spirit (X3) to the dependent variable, namely the level of teacher work discipline $(Y)$. In order for the results of the questionnaire data to not be out of necessity in the study, then the points of this instrument are designed to be closed in nature, meaning that the respondents have prepared alternative answers and each alternative answer has a certain score or value. In this study the questionnaires using a Likert scale in the form of a check list with alternative answers given a score of I, 2 , 3 , and 4 .

\section{Data analysis}

\section{Test Validity and Reliability}

Before being used in assessment, the observation sheet is first tested for validity and reliability testing. An instrument is said to be valid if it can reveal data 
from variables that are properly examined. Calculation of validity in this study was carried out using the SPSS 22 program. If $\mathrm{rxy}>\mathrm{r}$ table, the questionnaire is said to be valid and if rxy $<\mathrm{r}$ the instrument table is said to be invalid. While reliability has the meaning to what extent the results of a measurement can be trusted (Barorah, 2013, p. 23). Reliability results can be seen from the results Cronbach's Alpha every variable is more than the minimum standard required, which is 0.60 , so the variables of leadership, work climate , work motivation and reliable performance are good as a data collection tool .

\section{Hypothesis testing}

Before testing the hypothesis, the researcher first conducted a pre-test which included normality test , linearity test and multikolinearitas test. After passing the prerequisite test the hypothesis followed by hypothesis testing in order to prove their influence school leadership, work climate and work spirit on teacher performance, either directly or indirectly by using some test analysis such as simple regression test, partial test (T-test), test coefficient of determination and path analysis (path analysis)

\section{Result and Discussion}

\section{Prerequisite Analysis Results}

The results of normality with the non-parametric statistical test used are the Kolmogorov-Smirnov OneSample test (KS-I Sample), each of the research variables has the Asymp value. Sig. (2-tailed) is greater than 0.05 , so the data of all variables in this study can be said to be normally distributed. While the results of the linearity of leadership variables, work climate and spirit towards work discipline variables produce data deviations from linear lines (deviation from linierity) $>$ 0.05 and significance value $<0.05$, it can be concluded that the data is in the form of linear functions and the regression model does not occur multicollinearity, it can be concluded that non multicollinearity data in the regression model

\section{Analysis Test Results}

Through the simple regression test, partial test ( $\mathrm{T}$ test), test coefficient of determination and path analysis (path analysis). Summary calculation of direct and indirect effect of leadership influence (XI), the work climate (X2) and work spirit (X3) on work discipline $(\mathrm{Y})$ through can be seen on the path coefficient tabel summary as follows:

Table I . Summary of Path Analysis Regression Analysis Results

\begin{tabular}{|c|c|c|c|c|c|}
\hline \multirow{2}{*}{ Variable Influence } & \multicolumn{2}{|c|}{ Regression Test } & \multirow{2}{*}{$\begin{array}{l}\text { Partial } \\
\text { Test }\end{array}$} & \multirow{2}{*}{$\begin{array}{c}\text { Determination } \\
\text { Test }\end{array}$} & \multirow{2}{*}{ Information } \\
\hline & Directly & Indirect & & & \\
\hline Leadership $\left(\mathrm{X}_{\mathrm{I}}\right)$-Discipline $(\mathrm{Y})$ & 0.523 & & 7.416 & 0.318 & Significant \\
\hline Leadership $\left(\mathrm{X}_{\mathrm{I}}\right)-$ Spirit $\left(\mathrm{X}_{3}\right)$ & 0.432 & & 5,370 & 0.194 & Significant \\
\hline $\operatorname{Spirit}\left(\mathrm{X}_{3}\right)$-Discipline $(\mathrm{Y})$ & 0.590 & & 7,600 & 0,329 & Significant \\
\hline Work Climate $\left(\mathrm{X}_{2}\right)$-Discipline $(\mathrm{Y})$ & $0.39 \mathrm{I}$ & & 5,289 & 0.189 & Significant \\
\hline Work Climate $\left(\mathrm{X}_{2}\right)$-Excitement $(\mathrm{X})$ & $0.55 \mathrm{I}$ & & 3,120 & 0.070 & Significant \\
\hline $\begin{array}{c}\text { Leadership }(\mathrm{X})-\text { Spirit }\left(\mathrm{X}_{2}\right)- \\
\text { Discipline }(\mathrm{Y}) \\
\end{array}$ & - & 0,238 & 4,367 & - & Significant \\
\hline $\begin{array}{c}\text { Work Climate }(\mathrm{X})-\text { Spirit }\left(\mathrm{X}_{2}\right) \\
\text {-Discipline }(\mathrm{Y})\end{array}$ & - & 0.215 & 2,868 & - & Significant \\
\hline
\end{tabular}

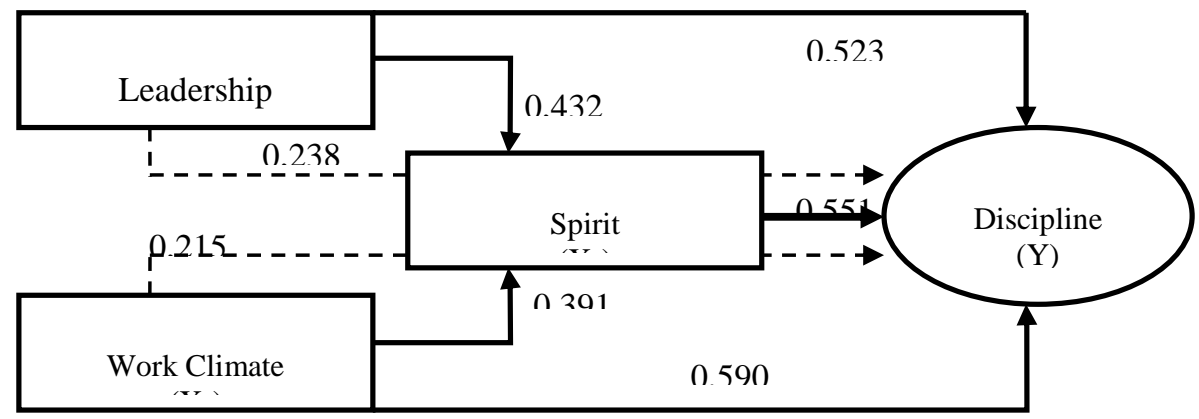

Figure I. Regression Path Analysis 


\section{Direct Effect of Leadership on Discipline Teachers of Elementary School working in the Batu Ampar District in Tanah Laut Regency}

Principal leadership is an important factor in improving the discipline of teachers, principals as school leaders, has an important role to mobilize, guide, protect, foster, set an example, encourage, and help teachers, students and staff in schools, roles and functions the most important thing for school principals is to move all the resources available in a school. So that it can be utilized maximally to achieve the stated goals (Aslamiah, 20I2, p. 50).

(Hasibuan, 2009, p. 87) explains that leadership is very instrumental in determining employee discipline because leaders are role models and role models by their subordinates. Leaders do not expect discipline of their subordinates well if he himself is not disciplined, because his behavior will be emulated and emulated by his subordinates. (Suriansyah, 2016, p. 46) explains that there are several factors that influence employee work discipline, one of which is the presence or absence of leadership models in the company. According to Singodimedjo, 2000 (Aslamiah, 2012, p. 48), that the factors that influence employee work discipline include the presence or absence of leaders in the company, leadership courage in taking action (sanctions/ penalties), the presence or absence of leadership supervision and the presence or absence of attention to employees.

(Hasibuan, 2009, p. 195) that several factors that influence employee work discipline are role models of a leader who plays a role in determining employee discipline, the actions of a leader who applies good justice will create good discipline as well as actions inherent in leadership realizing discipline.

Overall the Leadership always tries to have his subordinates have good discipline. A leader is said to be effective in his leadership, if his subordinates are well disciplined. Exemplary leadership plays a role in determining employee discipline because leaders are role models and role models by their subordinates. The leader must set an example that is good, disciplined, honest, fair, and in accordance with the word with actions. With the example of a good leader, the discipline of subordinates will also be good (Danim, 2012, p. I54).

Direct Effect Leadership to Work Spirit in Elementary School Teachers on the Batu Ampar district of Tanah Laut Regency
According to (Aslamiah, 2012, p. I0) one of the important competencies that must be owned by a leader is the ability to be able to motivate his subordinates. The principal acts as a motivator for both the subordinates and the surrounding environment. (Rivai, 2014, p. I20) In addition, a leader must have inspirational motivation where the leader has time to communicate with employees and can provide motivation to subordinates to do their jobs to the fullest. Leaders also motivate teachers to improve the competence and careers of teachers by giving teachers the opportunity to take part in various trainings or develop higher education.

(Sutarto, 20II, p. 9I) Leaders with sincerity motivate teachers in working at a minimum of reinforcement and praise in a fair and equitable manner and most importantly a leader always be open in any criticism and suggestions or in dealing with any existing problems. With the attitude and nature of leadership it will certainly make motivation for teachers to be high.

The enthusiasm of the teacher's work needs to get the attention of the principal as the leader. (Rasyidah, 2019 , p. I65) The work spirit is a factor that originates from within the teacher himself in the form of the desire to do his job better without pressure from anyone. Teachers who have high spirit will certainly always try in various ways so that the tasks they carry out achieve the desired goals. All these things are very necessary in achieving the success of the school learning process. It can be said in other words that teachers who have a passion for work will succeed in carrying out the learning process in the classroom.

According to (Danim, 20I2, p. I5I) which states that the power and influence of leaders in increasing spirit can be seen through interactions (relationships, tasks, position power) between, superiors and subordinates. In accordance with the results of the respondents' answers, some indicators of leadership greatly influence the teacher's work spirit in working as principal's intellectual stimulation with the intelligence of the principal or the leader. Leaders are able to manage and implement good working relationships with their subordinates or teachers as always informing all notices to the teacher, leadership intelligence is seen from how to solve all problems in school leaders always conduct deliberations with subordinates before making decisions and are open to accept suggestions. Intellectual leadership in motivating teachers is seen from the division of tasks of the teachers, even though it is conducted by deliberation but the leader must be sensitive in understanding the character of the teacher so that the 
delegation of tasks must be in accordance with the abilities of the teachers.

Partially the influence of the leadership on the teacher's work spirit can be seen individually (principal), meaning that there is concern for the individual teacher from the principal. Leadership also gives positive and significant influence on teacher work spirit. (Rahayu, 20I4, p. 89) One of the leaders' roles that most influences teacher spirit is the attitude of the leader who is open and always listening or sensitive to what the teacher wants. The teacher will be motivated if all desires that are part of improving the learning process itself can be heard by the leader as the teacher listens to and values the opinions of the students. A good leader will always give his subordinates the opportunity to talk to listen to what they need and expect, because listening to the intentions and good wishes of a teacher will further strengthen the teacher's work spirit, they feel valued and needed.

\section{Direct Effect of Work Climate to Work Discipline Teachers in Elementary School on the Batu Ampar of Tanah Laut Regency}

The organizational climate has six elements including: compatibility, responsibility, work standards, rewards, clarity and team spirit. Based on the results of the study, compatibility with colleagues and leaders as well as open interaction and communication is the element that has the highest value that affects the work climate in elementary school Batu Ampar District Tanah Laut Regency. Indicators that show supportive interactions within the organization are communication patterns and individual interaction patterns. (Sutarto, 201I, p. I07) explains that employees in work need a supportive climate to interact and work with colleagues or work groups. The benefit of interaction between individuals in the workplace is being able to exchange information, experience, and most importantly the social relations of colleagues can be harmoniously established so as to make employees feel comfortable and happy, not feeling depressed and free to realize themselves in showing their abilities.

One characteristic of the influence of the work climate on teacher discipline is because teachers feel that the work climate is built by really paying attention to their needs and problems. The working climate pattern in terms of communication built made-led formal and informal communication $\mathrm{n}$ already good enough that can improve the atmosphere of warmth and kinship is able to build relationships harmonious enough between of all teachers so that this makes it easier in the formation and improvement of teacher discipline. Teachers feel that they are not under pressure or coercion in carrying out discipline but with a good work climate fosters awareness or commitment in obeying existing regulations. According to (Sutrisno, 2012, p. 107), discipline is one of our self-respect for a company's rules and regulations contained in an employee, this will cause him to be able to adjust without coercion to an organization's rules and regulations.

\section{Direct Effect Work Climate to Work Spirit Teachers Elementary School in the Batu Ampar district of Tanah Laut Regency}

One of the important factors influencing employee spirit is the work climate, because all the characteristics or characteristics that exist or are felt are present in the work climate and arise mainly due to organizational activities carried out consciously or unconsciously. Organizational climate influences the behavior of someone who influences the way of life, who he relates to, who he likes, how he works, what he wants to achieve, and how he adjusts to the organization, even the work climate in the organization has a direct influence on enthusiasm the work of the teacher who carries out the teaching process, in order to achieve this goal, a work climate must be able to be built by taking into account all the problems that affect the work process smoothly and efficiently. (Wirawan, 2007, p. 120) states that employees who feel comfortable with the climate of work, tend to work more effectively and enjoy the work process compared to employees who feel uncomfortable.

The influence of the work climate on work spirit in elementary school in Batu Ampar District, Tanah Laut Regency is illustrated One of the things that can create an organizational climate is the opportunity for promotion in accordance with the work performance of employees and the appreciation and cohesiveness in work. A work climate with a work atmosphere, relationships with work colleagues and the availability of comfortable work facilities can provide the teacher peace in working so that his performance is optimal. Although the results of the study show a strong influence of the work climate variable on teacher motivation in Batu Ampar District, Tanah Laut Regency, but not all of them can show a high level of work motivation. This is caused by a changing work climate so that changes in the work climate have a strong influence, where changes in the work climate can increase motivation towards more and lead to the ability of teachers to work as a team work. 
Direct Effect Work Spirit to Work Discipline Teachers in Elementary School on the Batu Ampar of Tanah Laut Regency

The spirit of work is an impulse that is contained in the teacher as a result of the influence that comes from within himself as well as from outside, which raises, directs, and organizes behavior to carry out the tasks he carries out. The measurement indicators of work spirit variables in this study refer to the general theory (Azwar, 2005, p. I80) which includes aggressive behavior, individual feelings in work, adjusting to the leader and coworkers, and ego involvement in work.

Results this research may prove work spirit teacher job Elementary School in the district of Batu Ampar Tanah Laut seen from indicators of aggressive behavior seen on the accuracy of finished work, the majority of the teachers have been very good and the scarcity of time delay in completing the work of the time limit specified and the majority complete the work in accordance with the teacher's ability. Spirit teachers' work had a significant influence in the discipline of work, according data shows that the teachers have following regulations in the organizational environment.

Awareness of unattended discipline shows a positive thing, the influence of leadership and applicable regulations. Regulations are intended to control the behavior of employees and keep directing employees to stay focused in carrying out tasks that are charged so that the process of achieving goals runs smoothly. (Aurelia Dewanggi, 2015, p. 160) The majority of teachers often come to work earlier than the specified time shows the high passion of employees to work or finish work. With the increasingly high level of work enthusiasm for the work received, it certainly will have an impact on the completion of the tasks carried out by a teacher who ultimately creates high work performance.

\section{Indirect Influence of Leadership through Work Spirit on Discipline of Teachers of Primary Schools in Batu Ampar District, Tanah Laut Regency}

There is an indirect influence of leadership on teacher discipline in Batu Ampar District, Tanah Laut Regency through work spirit variables, this proves good leadership will encourage or encourage all teachers to be more active in work and feel valued so that it will work optimally. According to (Wahjosumidjo, 2007, p. 9I) one of the important competencies that must be possessed by a leader is the ability to be able to motivate or give enthusiasm to his subordinates. The spirit of work can arise due to several things, both from within and from outside ourselves. Some things that can influence the emergence of employee spirit include leadership, working conditions and work colleagues.

According to (Aslamiah, 20I2, p. 5I) one of the important competencies that must be owned by a leader is the ability to be able to motivate his subordinates. The principal acts as a motivator for both the subordinates and the surrounding environment. Leadership has a very large influence in improving employee performance, because the role model leaders and the spotlight from subordinates. Thus if an organization wants to have high performance, leadership is needed that is able to move the subordinates so that they feel motivated to do work with high performance.

Based on the facts in the field according to the perceptions of the respondents stating that the spirit of the teachers in Elementary School Batu Ampar district Tanah Laut Regency still needs improvement and improvement. This shows the direct influence of the leadership more directly on teacher discipline than through work spirit. These results prove that the leadership decisions relating to discipline in direct better than through spirit as intervening or mederator, the leadership of principals better directing, guiding teachers and establish direct communication that will improve work discipline for teachers.

The principal is still more oriented towards the implementation of duties and the implementation of tasks is limited by formal regulations, supervision or supervision of the implementation of duties of employees still seem tight and too formal, the work atmosphere is still more formalistic. (Tawas, 2016, p. I42) This condition results in low spirit. It is seen that there is still a lack of encouragement or enthusiasm to work as well as possible to achieve high achievements, to gain recognition for achievements, to make progress in careers and to develop knowledge and skills in the framework of self-development. Low work spirit can also be seen from teacher behavior such as if there is no supervision from the principal, the teacher does not utilize the work time optimally, likes to delay the implementation of work assignments, lacks enthusiasm to finish work earlier than the specified time, does not like to take initiative and creativity in carrying out work tasks.

Indirect Effects of School Work Climate through Work Spirit on Work Discipline of Elementary School Teachers in Batu Ampar District, Tanah Laut Regency

Climate school work has a comfortable and pleasant school organizational atmosphere that allows stimulating the teachers to work passionately, this fosters the enthusiasm of the teachers in having a sense of responsibility for their position and duties. This be- 
comes important, because attendance or attendance can be a benchmark of responsibility and spirit that employees have, if employees often default to work it affects the activities of the organization where the teacher is a sub-system of a school organization. School work climate can influence the enthusiasm and work discipline of the teacher. Through the support of a conducive school work climate, the principal has concern, the teacher feels comfortable and is protected from feeling depressed and has confidence in his performance. Therefore, the teacher's work spirit becomes increasingly high which is shown through good responsibility and discipline (Wirawan, 2007, p. I03).

Based on the results of path analysis in this study, it is known that the work climate has a more positive and significant effect on teacher discipline than the influence of the work climate through intervening variables of work spirit towards teacher discipline (indirectly). This can be interpreted that the work climate variable can directly influence discipline without going through work spirit. This is because the organizational climate influences the behavior of a worker, which influences the way of life, to whom he relates, who he likes, how his activities work, what he wants to achieve, and how he adjusts to the organization. Besides that, the discipline is beneficial to educate employees to comply with and enjoy existing regulations, procedures, and policies, so that they can produce good performance.

Lack of knowledge about existing regulations, procedures and policies is the most common cause of disciplinary action. The work climate is far more important in influencing a person's behavior at work than his work spirit. Although the teachers have a high spirit in work but if it is not supported by a good work climate such as clarity in the distribution of authority and responsibility, clear work rules, compatibility and harmony in relations with the leader or co-workers, a high spirit will be in vain drain.

\section{Conclusion}

The conclusions of this study are that the principal's leadership, work climate and work spirit have a positive influence on the discipline of elementary school teachers teachers in Batu Ampar Subdistrict Tanah Laut Regency. The principal's leadership and work climate through work spirit a positive influence on the discipline of elementary school teachers in Batu Ampar District Tanah Laut Regency.

\section{Acknowledgment}

Authors thanks to Magister Program of Educational Manajement, Lambung Mangkurat University Banjarmasin for facilitating and supporting our research.

\section{References}

Arikunto, S. (2010). Prosedur Penelitian: Suatu Pendekatan Praktik. Jakarta: PT. Rineka Cipta. Aslamiah. (2012). Menuju Kepala Sekolah Efektif dari Teorits ke Praktis. Rumah Pengetahuan.

Aurelia Dewanggi, H. (20I5). Pengaruh gaya kepemimpinan dan budaya organisasi pada kinerja guru dengan motivasi sebagai variabel intervening (studi pada guru di sekolah menengah atas Wonogiri. Dinamika Manajemen, vol I, no.5, hal I-2, I60.

Azwar, S. (2005). Sikap Manusia, Teori dan Pengukurannya. Yogyakarta: Pustaka Pelajar.

Barorah, A. (2013). Analisis Multivariat SPSS 21 Series. Jakarta: Kompas Media.

Danim, S. (2012). Motivasi Kepemimpinan dan Efektivitas Kelompok. Jakarta: PT. Rineka Cipta.

Hasibuan, M. S. (2009). Manajemen Sumber Daya Manusia (edisi revisi), Jakarta Bumi Aksara. Jakarta: Bumi Aksara.

Prasetyo, B. (2005). Metode Penelitian Kuantitatif: teori dan aplikasi. Jakarta: Raja Grafindo Persada.

Prijadarminto, S. (2003). Kepatuhan sebagai suatu perilaku. Jakarta: CV Balai Pustaka.

Rahayu, E. D. (20I4). Pengaruh Gaya Kepemimpinan dan Iklim Kerja terhadap Disiplin Kerja dengan intervening Semangat Kerja pada pegawai Badan Kepegawaian Daerah Kota Semarang. JATI Undip, Vol VII, No 2, 89.

Rasyidah. (2019). Pengaruh Kepemimpinan, Iklim Kerja dan Motivasi terhadap Kinerja Guru Sekolah Dasar Negeri di Kecamatan Banjarmasin Utara. International Journal of Scientific Development and Research (IJSDR) I90I023, Volume 4, Issue I, I42.

Rivai, V. (2014). Performance appraisal sistem yang tepat untuk menilai kinerja karyawan dan meningkatkan daya saing perusahaan. Jakarta: Raja Grafindo Persada.

Sugiyono, D. (2000). Metode Penelitian. Bandung: CV. Alfabeta.

Suriansyah, Ahmad. (2015). Strategi Pembelajaran. Jakarta: PT. Raja Grafindo Persada. 
ISSN 2580-2135

Suriansyah, Ahmad. (2016). Profesi Kependidikan "Persfektif Guru Profesional". Jakarta: PT. Raja Grapindo Persada.

Sutarto. (201 I). Dasar-Dasar Kepemimpinan Administrasi. Yogyakarta: Gadjah Mada University Press.

Suwatno, Y. d. (20II). Manajemen Sumber Daya Manusia. Bandung: Alpabeta.

Tawas, H. (2016). Pengaruh perilaku pimpinan dan motivasi kerja terhadap disiplin kerja (Studi Pada Tenaga Kerja Outsourcing di PT.
TELKOM Manado. Jurnal EMBA Vol.4 No.4 ISSN 2303-II74, I42.

Wahjosumidjo. (2007). Kepemimpinan Kepala Sekolah, Tinjauan Teoritik dan Permasalahannya. Jakarta: PT. Raja Grafindo Persada.

Wirawan. (2007). Evaluasi Kinerja Sumber Daya Manusia: teori, praktik, dan penelitian. Jakarta: Salemba Empat. 